\title{
Production, quality and livestock carrying capacity of Panicum maximum and Sesbania grandiflora at saline soil with different manure application
}

\author{
F. Kusmiyati ${ }^{1{ }^{1 * *}, \text { E. Pangestu }}{ }^{2}$, S. Surahmanto ${ }^{2}$, E.D. Purbajanti ${ }^{1}$ and B. Herwibawa ${ }^{1}$ \\ ${ }^{1}$ Departemen of Agricultural Science, Faculty of Animal and Agricultural Sciences, \\ Diponegoro University, Tembalang Campus, Semarang 50275, Central Java - Indonesia \\ ${ }^{2}$ Departemen of Animal Science, Faculty of Animal and Agricultural Sciences, \\ Diponegoro University, Tembalang Campus, Semarang 50275, Central Java - Indonesia \\ *Corresponding E-mail: fkusmiyati@live.undip.ac.id
}

Received June 11, 2019; Accepted August 26, 2019

\begin{abstract}
ABSTRAK
Penelitian ini bertujuan untuk mengkaji pengaruh pupuk kandang pada tanah salin terhadap produksi hijauan, kualitas dan daya tampung ternak dari P. maximum dan S. grandiflora. Penelitian dilaksanakan pada tanah salin dengan tingkat salinitas sedang di Kabupaten Rembang, Provinsi Jawa Tengah, Indonesia. Rancangan yang digunakan adalah rancangan acak kelompok. Perlakuan adalah dosis pupuk kandang yaitu 0 ton/ha, 10 ton/ha dan 20 ton/ha. Tanaman pakan dalam penelitian ini adalah rumput benggala (Panicum maximum) dan legum turi (Sesbania grandiflora) yang ditanam secara monokultur dan tumpangsari. Parameter yang diukur adalah produksi bahan kering (BK) hijauan, abu, protein kasar (PK), serat kasar (SK), lemak kasar (LK) dan total digestibe nutrients (TDN). P. maximum dipotong 8 kali, sedangkan $S$. grandiflora dipotong 6 kali selama satu tahun. Hasil penelitian menunjukkan bahwa produksi bahan kering tertinggi pada perlakuan tumpangsari P. maximum dan $S$. grandiflora dengan aplikasi pupuk kandang 20 ton/ha. Produksi BK, produksi PK dan produksi TDN tersedia pada perlakuan aplikasi pupuk kandang 20 ton/ha berturut-turut adalah $29.131 \mathrm{~kg} / \mathrm{ha} / \mathrm{tahun}$; $3.722 \mathrm{~kg} / \mathrm{ha} /$ tahun dan $17.718 \mathrm{~kg} / \mathrm{ha} /$ tahun. Daya tampung ternak berdasarkan BK, PK dan TDN berturut-turut adalah 10,8 ST/ha/tahun; 13,6 ST/ha/tahun dan 11,3 ST/ha/tahun. Kesimpulan, peningkatan pupuk kandang sampai dosis 20 ton/ha di tanah salin meningkatkan produksi, protein kasar hijauan serta daya tampung ternak,
\end{abstract}

Kata kunci: monokultur, protein kasar, satuan ternak, TDN, tumpangsari

\section{ABSTRACT}

The objective of this study was to evaluate the effect of manure at saline soil on forage production, quality and livestock carrying capacity of P. maximum and S. grandiflora. The research was conducted on moderately saline soil at Rembang Regency, Central Java Province, Indonesia.Randomized complete block design was used as design experiment. The treatments were different dosage of manure as organic amendment $(0,10$ and 20 tonnes/ha). Forage crops were $P$. maximum and $S$. grandiflora that planted monoculture or mixed-cropping. Parameters measured were dry matter (DM) production, ash, crude protein, crude fibre, ether extract, total digestible nutrients. $P$. maximum was cut eight times, $S$. grandiflora was cut six times during one year. The result showed that the highest total dry matter production of mixed cropping P. maximum and S. grandiflora was available at moderately saline soil with application 20 ton/ha manure. Total production of dry matter, crude protein and total digestible 
nutrient available at application 20 ton/ha manure were $29131 \mathrm{~kg} / \mathrm{ha} /$ year; $3722 \mathrm{~kg} / \mathrm{ha} /$ year and 17718 $\mathrm{kg} / \mathrm{ha} /$ year, respectively. Carrying capacity based on dry matter, crude protein and total digestible nutrients were $10.8 \mathrm{AU} / \mathrm{ha} /$ year; 13.6 AU/ha/year and 11.3 $\mathrm{AU} / \mathrm{ha} /$ year, respectively. In conclusion, application of 20 ton/ha manure at saline soil increased production, crude protein and carrying capacity.

Keywords: animal unit, crude protein, mixed cropping, monoculture, Total Digestible Nutrient

\section{INTRODUCTION}

One of the main problems that decreases crop production on agricultural land is salinity because most of crop are sensitive to high salt concentration. The area of salt affected is increasing year by year (Shrivastava and Kumar, 2015). Preliminary findings suggest that plants which grow at saline soil encounter osmotic stress, ion toxicity, nutrient deficiency and oxidative stress. Osmotic stress occurs because of the presence of salt in soil solution, consequently it reduces soil water potential and the plant ability to absorp water. The toxic ions found in saline soil are sodium $\left(\mathrm{Na}^{+}\right)$and chloride $\left(\mathrm{Cl}^{-}\right)$which have detrimental effects when accumulated in concentration over the tolerance threshold in plants (Bano and Fatima, 2009). The tolerence threshold of some plants is starting at electrical conductivity of $2 \mathrm{dS} / \mathrm{m}$ (Vargas et al., 2018).

Many studies have been undertaken to ameliorate saline soil so that it is suitable as agricultural land. Wu et al. (2018) stated that using organic amendment such as cattle dung, vermicompost and biofertilizer improved the soil organic matter content and soil organism at saline soil. While Mbarki et al. (2018) reported, compost application of municipal solid waste compensated salinity adverse effects on nutrient uptake and plant growth. Kusmiyati et al. (2018) reported, application of 20 ton/ha manure at saline soil increased growth and dry matter production of $S$. grandiflora at first and second cutting. Recording temporal and spatial changes of water quality and soil salinity was suggested by Qureshi and AlFalahi (2015). Modification of micro climate using mulch at saline soil was another way to reduce salinity negatif effect on plant growth (Kusmiyati et al., 2016). Other approach of using saline soil as agricultural land is utilizing salt tolerance plant (Rui-dong, 2018 and Diaz et al., 2018). Ahmad et al. (2010) stated that reduction of photosynthetic capacity was lower at salttolerant populations compared to salt-sensitive populations. Our previous studies showed that among 5 grasses (Panicum maximum, Euchlaena mexicana, Setaria sphacelata, Cynodon plectostachyus and Brachiaria brizantha), $P$. maximum showed the most tolerant grass based on mineral concentration at saline soil (Kusmiyati et al., 2012).

Panicum maximum and Sesbania grandiflora are usually used as forage crop in Indonesia. Forage crop could grown either in pastures as feed for grazing animal or in field as feed to livestock in confinement by cut and carry. Olanite et al. (2009) reported dry matter production annually of $P$. maximum was 10.2 ton/ha at pasture in savanna area that has sandy soil with low in nitrogen and available phosphorus, fairly acidic. Dry matter production commonly was used to calculate the average number of cattle that an area supported safely for a season, it is called as carrying capacity. Carrying capacity of Panicum maximum in the Amazon biome - Brazil was 2.86 AU/ha for production of beef cattle (Andrade et al., 2013). Rinduwati et al. (2016) reported carrying capacity of pasture that dominated with 15 species such as Cyperus rotundus, Calopogonium muconoides, Axonopus compressus, Crotalaria juncea and Desmodium intortum at Gowa Regency in Indonesia was 0.88 AU (Animal Unit)/ha/year. Meanwhile, Se'u et al. (2015) evaluated dry matter production of grass was 150 to $390 \mathrm{~kg} / \mathrm{ha} /$ year that could support 0.24 to $0.63 \mathrm{AU} / \mathrm{ha} /$ year in Timor Tengah Selatan Regency in Indonesia.

Based on previous research, amelioration efforts on saline soil as agricultural land was only based on single methods (Wu et al., 2018). Combining two or more methods on using saline soil as agricultural land has not done yet. So, this research combines two methods, using plant tolerance and organic amendment. Plant tolerance at this research are $P$. maximum and $S$. grandiflora that are usually used as forage crop. Prior study did not reported the production, quality and carrying capacity of $P$. maximum and $S$. grandiflora at saline soil. Therefore, this experiment was conducted to evaluate the effect of manure as organic amendment on production, quality and livestock carrying capacity of $P$. maximum and $S$. grandiflora based on cut and carry at saline soil. 


\section{MATERIALS AND METHODS}

\section{Study Area}

This research was conducted on moderately saline soil from June 2016 to July 2017 at Kaliori, Rembang Regency, Province of Central Java, Indonesia. Rembang regency is located on the north coast of Java island at $3 \mathrm{~m}$ above sea level. The number of raindays, annual rainfall, average temperature and relative humidity were 72 days, $1716 \mathrm{~mm}, 30^{\circ} \mathrm{C}$ and $42 \%$, respectively (Badan Pusat Statistik Kabupaten Rembang, 2017). Type of soil was alluvial with $\mathrm{pH} 7.8$ and texture of silt loam. Total nitrogen, $\mathrm{P}_{2} \mathrm{O}_{5}, \mathrm{~K}_{2} \mathrm{O}$, organic $\mathrm{C}$ were $0.13 \%, 75.65 \mathrm{mg} / 100 \mathrm{~g}, 140.20 \mathrm{mg} / 100 \mathrm{~g}, 1.08$ $\%$, respectively. Sodium exchangeable and cation exchange capacity were $0.37 \mathrm{Cmol} / \mathrm{kg}$ and 11.99 $\mathrm{Cmol} / \mathrm{kg}$. The electrical conductivity (EC) was 3.8 $\mathrm{dS} / \mathrm{m}$ during rainy season and $4.1 \mathrm{dS} / \mathrm{m}$ during dry season.

\section{Design and Treatment}

The design experiment used randomized complete block design. There were three blocks based on different soil salinity. The treatments were different dosage of manure as organic amendment $(0,10$ and 20 tonnes/ha). The forage crops were $P$. maximum and $S$. grandiflora which planted monoculture or mixed-cropping. There were nine treatments with three blocks as replicates. Each treatment was used plot of $6 \mathrm{~m} \mathrm{x}$ $7 \mathrm{~m}$. Total plots were 27 plots. Soil tillage was done before planting. Application of manure was done after soil tillage and one week before planting. $\mathrm{pH}, \mathrm{C}$-organic, total $\mathrm{N}, \mathrm{P}_{2} \mathrm{O}_{5}, \mathrm{~K}_{2} \mathrm{O}$ and $\mathrm{C} / \mathrm{N}$ ratio of manure were $6.56 ; 30.64 \% ; 1.65 \%$; $9.27 \% ; 3.52 \%$ and 18.55 ; respectively. Manure was produced by the fermentation of fresh cattle dung from farmers in the study area.

Crown splits of $P$. maximum or seed of $S$. grandiflora were planted at $75 \mathrm{~cm} \times 100 \mathrm{~cm}$ at monoculture. While at mixed cropping, the second plant was planted between rows. Forage crops both at monoculture and mixed cropping were planted concurrently. Fertilizers were applied according to recommendation dosage (60 $\mathrm{kg} \mathrm{N} / \mathrm{ha} /$ cutting, $150 \mathrm{~kg} \mathrm{P}_{2} \mathrm{O}_{5} / \mathrm{ha}$ and $100 \mathrm{~kg}$ $\mathrm{K}_{2} \mathrm{O} /$ ha). First, $P$. maximum was cut four weeks after planting. No parameter was measured at first cut. Following cutting of $P$. maximum was carried out before generative stage. First, $S$. grandiflora was cut thirteen weeks after planting. The next cut of $S$. grandiflora was done every 7 weeks. Height of cutting of $P$. maximum and $S$. grandiflora were
$10 \mathrm{~cm}$ and $30 \mathrm{~cm}$ above soil, respectively.

Parameter measured was dry matter (DM) production at every cutting. Crude protein, ash, crude fibre, ether extract and nitrogen free extract (NFE) were measured at eight cutting of $P$. maximum and sixth cutting of $S$. grandiflora. Crude protein, ash, crude fibre and ether extract were analysed by proximate analysis according to AOAC (2005). Total digestible nutrient (TDN) was calculated based on proximate analysis (Hartadi et al., 1980). The formula for TDN calculation was:

$$
\begin{aligned}
& \text { TDN }(\%)=37.937-1.018(\mathrm{CF})-4.886 \\
& (\mathrm{EE})+0.173(\mathrm{NFE})+1.042(\mathrm{CP})+0.015 \\
& (\mathrm{CF})(\mathrm{CF})-0.068(\mathrm{EE})(\mathrm{EE})+0.008(\mathrm{CF}) \\
& (\mathrm{NFE})+0.119(\mathrm{EE})(\mathrm{NFE})+0.038(\mathrm{EE}) \\
& (\mathrm{CP})+0.003(\mathrm{EE})(\mathrm{EE})(\mathrm{CP}) \\
& \text { Dry matter production was also utilized to }
\end{aligned}
$$
calculate Land Equivalent Ratio (LER). In addition, land equivalent ratio (LER) was used to evaluate mixed cropping efficiencies with respect to monoculture/sole crop. It was expressed as $\mathrm{LER}=\mathrm{M} a / \mathrm{S} a+\mathrm{M} b / \mathrm{S} b$, where $\mathrm{M}$ and $\mathrm{S}$ refer to mixed cropping and monoculture/sole crop yield respectively, and the subscripts $a$ and $b$ indicate the component crops in the mixture.

\section{Analysis data}

Dry matter (DM) production, crude protein, crude fibre and ether extract were analyzed using analysis of variance, followed by Duncan's multiple range test. Statistical model was :

Where :

$$
\mathrm{Y}_{\mathrm{ij}}=\mu+\mathrm{T}_{\mathrm{i}}+\mathrm{B}_{\mathrm{j}}+\varepsilon_{\mathrm{ij}}
$$

$\mathrm{Y}_{\mathrm{ij}}=$ The observation at $\mathrm{i}^{\text {th }}$ treatment and $\mathrm{j}^{\text {th }}$ block $\mu=$ Overall mean

$\mathrm{T}_{\mathrm{i}}=$ Effect of $\mathrm{i}^{\text {th }}$ treatment $(\mathrm{i}=1,2,3,4,5,6,7,8$ and 9)

$B_{j}=$ Effect of $j^{\text {th }}$ block $(j=1,2$ and 3$)$

$\varepsilon_{\mathrm{ij}}=$ Effect of error

Carrying capacity was calculated based on dry matter production, crude protein and total digestible nutrients. The procedure to calculate carrying capacity used the modification methods of Se'u et al. (2015) : (1) Calculation P. maximum $\mathrm{DM}$ production $(\mathrm{kg} / \mathrm{ha} /$ year $)=$ sum of $\mathrm{DM}$ production from second cutting to eight cutting at mixed cropping. Total dry matter production of $P$. maximum at second cutting and third cutting at 0 ton/ha, 10 ton/ha and 20 ton/ha manure application were $1996.5 \mathrm{~kg} / \mathrm{ha}, 7087.3 \mathrm{~kg} / \mathrm{ha}$ and $10444.2 \mathrm{~kg} / \mathrm{ha}$, respectively (Kusmiyati et al., 
2017). (2) Calculation S. grandiflora DM production $(\mathrm{kg} / \mathrm{ha} /$ year $)=$ sum of DM production from first cutting to sixth cutting at mixed cropping. Dry matter production of $S$. grandiflora at first cutting at 0 ton/ha, 10 ton/ha and 20 ton/ha manure application were $1079.4 \mathrm{~kg} / \mathrm{ha}, 2086.4$ $\mathrm{kg} / \mathrm{ha}$ and $2591.5 \mathrm{~kg} / \mathrm{ha}$, respectively (Kusmiyati et al., 2017). (3) Proper use factor (PUF) is $70 \%$.

(4) Calculation of Total DM production available at mixed cropping $(\mathrm{kg} / \mathrm{ha} /$ year $)=(P$. maximum DM production x PUF $)+(S$. grandiflora $\mathrm{DM}$ production $\mathrm{x}$ PUF). (5) Daily DM forage requirement for 1 animal unit (AU) is $7.4 \mathrm{~kg} /$ day or $2701 \mathrm{~kg} /$ year (Kearl, 1982). Assumption used for definition of one animal unit is steer with body weight of $300 \mathrm{~kg}$ and $0.75 \mathrm{~kg}$ of average daily gain. (6) Calculation carrying capacity based on $\mathrm{DM}(\mathrm{AU} / \mathrm{ha} /$ year $)=$ Total $\mathrm{DM}$ production available/DM requirement for one year. (7) Calculation carrying capacity based on crude protein production available $(\mathrm{AU} / \mathrm{ha} / \mathrm{year})=$ Crude protein production available $(\mathrm{kg} / \mathrm{ha} /$ year $) /$ $\mathrm{CP}$ requirement (kg/AU/year). Crude protein requirement for one year $(\mathrm{kg} / \mathrm{AU} /$ year $)=0.75$ $\mathrm{kg} /$ day x 365 day $=273.75 \mathrm{~kg} /$ year (Kearl, 1982). Crude protein production available $(\mathrm{kg} / \mathrm{ha} /$ year $)=$ (Total DM production available of $P$. maximum $\mathrm{x}$ $\%$ CP of $P$. maximum $)+(($ Total DM production available of $S$. grandiflora x \% CP of $S$. grandiflora). (8) Calculation carrying capacity based on total digestible nutrients production available $(\mathrm{AU} / \mathrm{ha} /$ year $)=$ total digestible nutrients production ( $\mathrm{kg} / \mathrm{ha} /$ year $)$ / TDN requirement (kg/AU/year). Total digestible nutrients requirement for one year $(\mathrm{kg} / \mathrm{AU} /$ year $)=4.3$ $\mathrm{kg} /$ day $\times 365$ day $=1569.5 \mathrm{~kg} /$ year (Kearl, 1982).Total digestible nutrients production available $(\mathrm{kg} / \mathrm{ha} /$ year $)=($ Total $\mathrm{DM}$ production available of $P$. maximum $\mathrm{x} \%$ TDN of $P$. maximum $)+($ Total DM production available of $S$. grandiflorax \% TDN of $S$. grandiflora).

\section{RESULTS AND DISCUSSION}

\section{Forage Production}

The result showed that manure application affected DM production of $P$. maximum either at monoculture or mixed cropping from fourth cutting until eight cutting (Table 1). Kusmiyati et al. (2017) reported DM production of $P$. maximum at second cutting has no significant difference between manure application of 0 ton/ha and 10 ton/ha. However, manure application affected DM production at third cutting. Manure application impact at saline soil on DM production of $P$. maximum was obvious from third cutting until eight cutting which application of manure increased significantly grass production. Dry matter production was higher at manure application of 20 ton/ha than at 10 ton/ha at fourth cutting, fifth cutting, seven cutting and eight cutting. The highest total DM production of $P$. maximum was at manure application of 20 ton/ha and monoculture. Meanwhile, the lowest was at no manure application and mixed cropping with S. grandiflora

The highest total DM production of $P$. maximum from fourth cutting to eight cutting was $22.8 \mathrm{ton} / \mathrm{ha} /$ year at aplication $20 \mathrm{ton} / \mathrm{ha}$ manure and monoculture (Table 1). The total DM production of $P$. maximum at saline soil in this study was higher than those reported by Ojo et al. (2013) and Olanite et al. (2009) . Ojo et al (2013) planted $P$. maximum at soil of sandy clay. While, Olanite et al. (2009) reported DM annual production of $P$. maximum was 10.2 ton/ha. $P$. maximum production at this study was based on cut and carry systems. Meanwhile, Olanite et al. (2009) calculated production of $P$. Maximum in a derived savanna area in Nigeria based on cattle grazing. Grazing by cattle is noted to contribute the DM production decline of pasture over times, especially when grazing pressure or stocking rates are high. The lowest DM production of $P$. maximum from fourth cutting to eight cutting was 2.9 ton/ha at treatment with no manure application and mixed cropping with $S$. grandiflora. The DM production was lower with that reported by Olanite et al. (2009).

Application of manure at saline soil also significantly improved DM production of $S$. grandiflora (Table 2). S. grandiflora production at manure aplication of 20 ton/ha was significantly higher than at manure aplication of 10 ton/ha from second cutting to sixth cutting, either at monoculture or mixed cropping with P. maximum. Total DM production of $S$. grandiflora at manure application of 20 ton/ha was greater and significantly different than at manure aplication of 10 ton/ha and 0 ton/ha.

Dry matter production of $S$. grandiflora at saline was increased at treatment of 10 ton/ha and 20 ton/ha manure both at monoculture and mixed cropping with $P$. maximum. An increase in total DM yield of $S$. grandiflora at monoculture, from $3.8 \mathrm{ton} / \mathrm{ha} /$ year to $7.6 \mathrm{ton} / \mathrm{ha} /$ year and $12.0 \mathrm{ton} / \mathrm{ha}$, as manure increased from 0 ton/ha to 10 ton/ha and 20 ton/ha. The yield of $S$. grandiflora at 

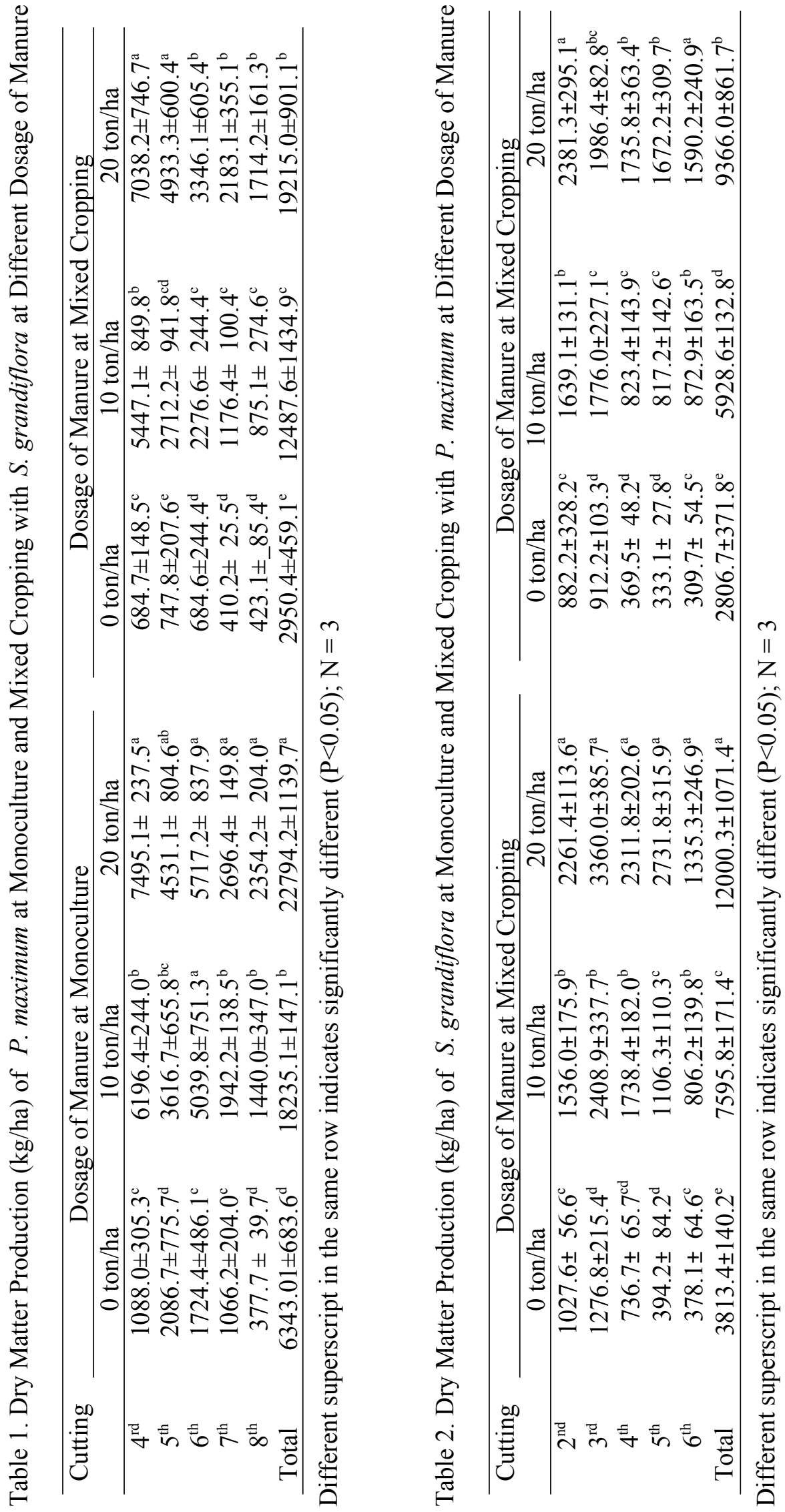
mixed cropping with $P$. maximum were $2.8 ; 5.9$ and 9.4 ton $\mathrm{DM} / \mathrm{ha} /$ year for manure application at 0,10 and 20 ton/ha respectively. The DM production at manure aplication was lower than those reported by Sarvade et al. (2014) whose reported green material of Sesbania grandiflora was 5.5 ton/ha or 11 ton/ha DM in 6.5 months.

Application of manure gave significant increase for DM production of $P$. maximum and $S$. grandiflora. The total DM produced by $P$. maximum or S. grandiflora either monoculture or mixed cropping at 20 ton/ha of manure were significantly $(\mathrm{P}<0.05)$ higher than the other treatment. Combining salt tolerant plant and organic amendent have more advantage in order to utilize saline soil as plant cultivation. $P$. maximum and $S$. grandiflora are tolerant forage crops at moderately saline soil (Kusmiyati et al., 2012). Salt tolerant plant capability to buffer the $\mathrm{Na}^{+}$increase in root meristem zone of cytosol cell is higher than salt-sensitive plants (Wu et al., 2015). Mechanism of plant tolerance to $\mathrm{Na}$ in saline soil are $\mathrm{Na}^{+}$exclusion, sequestration of vacuolar $\mathrm{Na}^{+}$, xylem $\mathrm{Na}^{+}$loading and uploading control, recirculation of $\mathrm{Na}^{+}$from shoot to root through phloem, $\mathrm{Na}^{+}$secretion by specialized salt glands (Wu, 2018). The second methods to ammeliorate saline soil in our research is through application of organic amendment. Organic amendment such as manure at saline soil improve and increase organism and organic matter of soil (Wu et al., 2018); accelerate $\mathrm{Na}$ leaching, decrease electrical conductity (EC) and exchange sodium percentage (ESP), increase infiltration and holding capacity of water, increase agregate stability (Wu et al., 2013); increase content of $\mathrm{N}$ and $\mathrm{P}$ in soil (Sastre-Conde et al., 2015). Our research finding suggests that plant production at moderately saline soil could be increased by using moderately tolerance plant such as $P$. maximum or $S$. grandiflora and organic amendment application. Organic amendment such as manure improve soil fertility including biological, physical and chemical properties of soil. Meanwhile, tolerant plant has better ability in enduring with overall salt stress effects. Combining two methods i.e. plant tolerance and organic amendment are better way in using saline soil as cultivation land.

Forage production of $P$. maximum and $S$. grandiflora at monoculture was greater than at mixed cropping in same dosage of manure. However, land use efficiency, calculated as land equivalent ratio (LER) was greater than one in all of manure treatment (Figure 1). The greatest LER (1.8) was achieved at mixed cropping of $P$. maximum and $S$. grandiflora with 20 ton/ha manure. This indicated that $80 \%$ more land would be needed in monoculture to yield the equal amount of dry matter production in mixed cropping. Land equivalent ratio at treatment no manure and 10 ton/ha manure were 1.4 and 1.6, respectively; it suggests that mixed cropping between $P$. maximum and $S$. grandiflora at moderately saline soil uses nutrient, water and air better than planted solely, and competition between those two plant is minimized. Our research explored the unique mixed cropping system between $\mathrm{C} 4$-grass ( $P$. maximum) and $\mathrm{C} 3-$ tree (S. grandiflora). Kimura et al. (2018) also evaluated mixed cropping system between C4grass (Panicum virgatum) and $\mathrm{C} 3$-tree (Populus

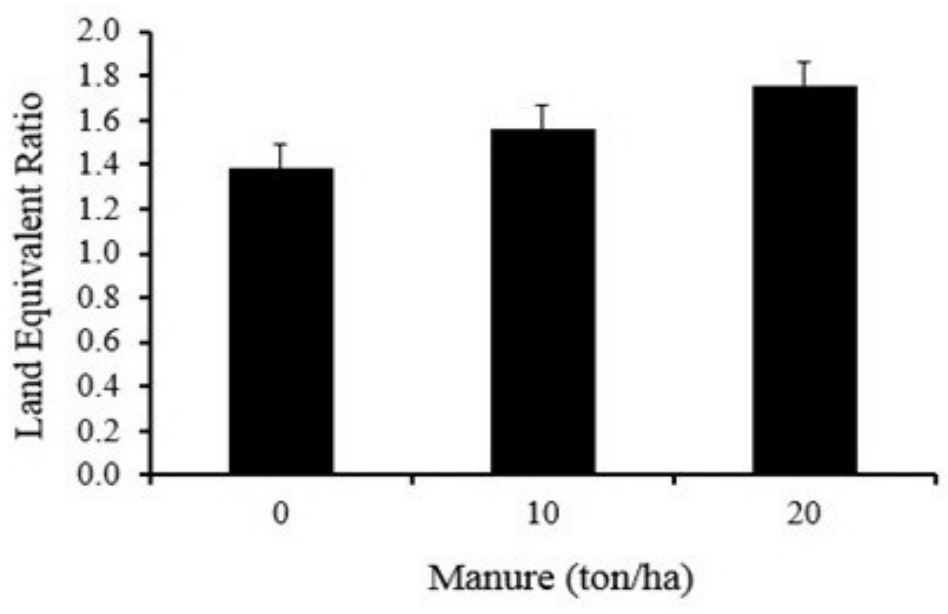

Figure 1. Land Equivalent Ratio (LER) at Different Dosage of Manure 
Table 3. Crude Protein (CP) (\%), Crude Fibre (CF) (\%) and Ether Extract (EE) (\%) of P. maximum and $S$. grandiflora at Different Dosage of Manure

\begin{tabular}{|c|c|c|c|c|c|c|}
\hline & \multicolumn{3}{|c|}{ Dosage of Manure at Mixed Cropping } & \multicolumn{3}{|c|}{ Dosage of Manure at Mixed Cropping } \\
\hline & 0 ton/ha & 10 ton/ha & 20 ton/ha & 0 ton/ha & 10 ton/ha & 20 ton/ha \\
\hline \multicolumn{7}{|c|}{ P. maximum } \\
\hline $\mathrm{CP}$ & $7.2 \pm 1.1 \mathrm{bc}$ & $7.8 \pm 0.6^{\mathrm{abc}}$ & $9.3 \pm 0.4^{\mathrm{a}}$ & $6.2 \pm 0.4^{\mathrm{c}}$ & $7.1 \pm 0.9 \mathrm{bc}$ & $8.3 \pm 1.6^{a b}$ \\
\hline $\mathrm{CF}$ & $26.8 \pm 0.5$ & $26.7 \pm 0.6$ & $27.0 \pm 0.1$ & $27.6 \pm 0.5$ & $28.1 \pm 1.3$ & $27.4 \pm 2.4$ \\
\hline $\mathrm{EE}$ & $1.8 \pm 0.4$ & $2.0 \pm 0.4$ & $1.9 \pm 0.2$ & $1.8 \pm 0.3$ & $2.0 \pm 0.7$ & $1.8 \pm 0.4$ \\
\hline \multicolumn{7}{|c|}{ S. grandiflora } \\
\hline $\mathrm{CP}$ & $17.7 \pm 0.7^{\mathrm{c}}$ & $21.0 \pm 0.6^{\mathrm{b}}$ & $23.9 \pm 1.8^{\mathrm{a}}$ & $20.5 \pm 0.9^{b}$ & $19.1 \pm 0.6^{\mathrm{bc}}$ & $23.8 \pm 2.2^{\mathrm{a}}$ \\
\hline $\mathrm{CF}$ & $12.2 \pm 0.1$ & $13.1 \pm 0.7$ & $13.5 \pm 0.3$ & $12.7 \pm 0.9$ & $13.5 \pm 1.6$ & $12.2 \pm 0.1$ \\
\hline $\mathrm{EE}$ & $3.6 \pm 0.5$ & $3.5 \pm 1.2$ & $3.7 \pm 0.4$ & $3.7 \pm 0.4$ & $3.8 \pm 0.9$ & $3.8 \pm 0.1$ \\
\hline
\end{tabular}

Different superscript in the same row indicates significantly different $(\mathrm{P}<0.05) ; \mathrm{N}=3$

spp) which has land equivalent ratio 1.4. Mixed cropping of forage crops improves $\mathrm{C}$ sequestration (Fang et al., 2010), feed quality and animal nutrition (Kebede et al., 2016). Forages in smallholder mixed farming systems have an crucial role in livestock nutrition, productivity and environmental sustainability (Ates et al., 2018).

\section{Forage Quality}

The result showed that crude protein of $P$. maximum at eight cutting and $S$. grandiflora at sixth cutting were affected significantly by dosage of manure. While, treatments were not affected crude fiber and ether extract of $P$. maximum and $S$.grandiflora. Crude protein of $P$. maximum at this research was varied between $6.2-9.3 \%$ (Table 3). Yoottasanong et al. (2015) reported crude protein of $P$. maximum at mixed cropping with Stylosanthes hamata at application of 8 ton/ha and 16 ton/ha manure were $9.6 \%$ and 9.4 $\%$, respectively. Crude fiber content in $P$. maximum was lower to $40.4 \%$ reported by Fadiyimu et al. (2010). Crude protein of S.grandiflora at saline soil was varied between $17.7-23.9 \%$. This value was equal to those reported by Kumar et al. (2017) whose recorded crude protein of S.grandiflora was $23.65 \%$.

Crude protein of $P$. maximum and S.grandiflora were increased significantly by adding manure at saline soil either at monoculture or mixed cropping (Table 3). The highest crude protein content of S.grandiflora was obtained by adding 20 ton/ha manure at saline soil. Manure application as organic amendment at saline soil increase $\mathrm{N}$ contents in soil (Sastre-Conde et al., 2015). Lee et al. (2017) stated forage nutritive value was increased by nitrogen fertilizer addition. Nitrogen addition to soil was positively related to crude protein, an increase of $100 \mathrm{~kg}$ $\mathrm{N} / \mathrm{ha} /$ year associated with a $2 \%$ increase in crude protein. Total nitrogen content of manure at this research was $1.65 \%$. Adding 20 ton/ha of manure indicated addition of $330 \mathrm{~kg} / \mathrm{ha}$ total $\mathrm{N}$ to saline soil. It was stated by Lee et al. (2017), addition of high rate $\mathrm{N}(350 \mathrm{~kg} \mathrm{~N} / \mathrm{h} /$ year) was correlated with a $7 \%$ increase in crude protein. An increase of crude protein at $P$. maximum and S. grandiflora at saline soil by adding 20 ton/ha were $2-3 \%$ and 3 $-6 \%$, respectively.

Forage quality such as crude protein, dry matter digestibility and palatability varied due to plant variety, maturity stages and management practices. Crude protein content decreases as forage moves from a vegetative stage to reproductive stage. Additionally, crude fiber increases during the same period. Crude fiber is an estimated measure of digestibility. Higher crude fiber means lower digestibility. Adding manure at saline soil will delay reproductive stage, so crude protein content of forage was still high and crude fiber was low. Crude protein levels of forages are essential for livestock. If the percentage of crude protein is low, intake and digestibility of livestock are reduced because the 
Table 4. Production Available of Dry Matter (DM), Crude Protein (CP), Total Digestible Nutrient (TDN) and Carrying Capacity of P. maximum and $S$. grandiflora at Different Dosage of Manure

\begin{tabular}{|c|c|c|c|c|}
\hline & \multirow{2}{*}{ Item } & \multicolumn{3}{|c|}{ Dosage of Manure at Mixed Cropping } \\
\hline & & 0 ton $/$ ha & 10 ton/ha & 20 ton/ha \\
\hline \multirow[t]{2}{*}{$\mathrm{DM}$} & Production $(\mathrm{kg} / \mathrm{ha} /$ year $)$ & $6183.1 \pm 513.3$ & $19312.9 \pm 1107.7$ & $29131.7 \pm 856.0$ \\
\hline & Carrying Capacity (AU/ha/year) & $2.3 \pm \quad 0.2$ & $7.2 \pm \quad 0.4$ & $10.8 \pm \quad 0.3$ \\
\hline \multirow[t]{2}{*}{$\mathrm{CP}$} & Production $(\mathrm{kg} / \mathrm{ha} /$ year $)$ & $771.2 \pm 91.9$ & $2048.9 \pm \quad 67.3$ & $3722.0 \pm 67.2$ \\
\hline & Carrying Capacity (AU/ha/year) & $2.8 \pm \quad 0.3$ & $7.5 \pm \quad 0.2$ & $13.6 \pm \quad 0.2$ \\
\hline \multirow[t]{2}{*}{ TDN } & Production (kg/ha/year) & $3826.2 \pm 338.8$ & $11429.1 \pm 587.4$ & $17718.3 \pm 396.9$ \\
\hline & Carrying Capacity (AU/ha/year) & $2.4 \pm 0.2$ & $7.3 \pm \quad 0.4$ & $11.3 \pm 0.3$ \\
\hline
\end{tabular}

$\mathrm{N}=3$

bacteria responsible for digestion can not sustain adequate level to process forage.

A proper proportion between protein and energy sufficiency is important to get high production of livestock. If farmers only used grass and legumes as feed, the availability of protein is sufficient. However, digestible energy availability is not sufficient (Tahuk et al., 2017). Feed which contain of $16 \%$ crude protein and $2850 \mathrm{Kcal} / \mathrm{kg}$ DM metabolizable energy increase high rate of feed intake of goat (Ginting et al., 2017). Tahuk et al. (2018) reported feed with proportion between crude protein level of $12 \%$ and TDN of $17 \%$ produced a higher-quality carcass and meat of male bali cattle.

\section{Carrying Capacity}

Based on Table 4, the highest total DM production of mixed cropping $P$. maximum and $S$. grandiflora was available at moderately saline soil with application 20 ton/ha manure as much as $29131 \mathrm{~kg} / \mathrm{ha} /$ year that could accommodate 10.8 $\mathrm{AU} / \mathrm{ha} /$ year. Total DM production available at application 10 ton/ha manure was 19312 $\mathrm{kg} / \mathrm{ha} /$ year that could accommodate as many as 7.2 $\mathrm{AU} / \mathrm{ha} /$ year, while total $\mathrm{DM}$ production available at no manure application was very low i.e. $6183 \mathrm{~kg} / \mathrm{ha} /$ year that was only able to accomodate as many as $2.3 \mathrm{AU} / \mathrm{ha} /$ year. Carrying capacity based on crude protein was higher than based on dry matter production. Carrying capacity based on crude protein and total digestible nutrients at application 20 ton/ha manure were 13.6 AU/ha/year and $11.3 \mathrm{AU} / \mathrm{ha} /$ year, respectively.
Carrying capacity of $P$. maximum and $S$. grandiflora at saline soil in our research was higher than those reported from natural pasture at Gowa Regency - Indonesia (Rinduwati et al., 2016) and Timor Tengah Selatan Regency Indonesia (Se'u et al., 2015). Forage crop at the natural pasture was dominated by native grasses which has genetically lower forage production. Potential pasture at Eastern Zone of Tanzania which consisted with 8 grasses and 7 legumes including P. maximum and Sesbania sesban was only able to support $0.2 \mathrm{TLU} / \mathrm{ha} /$ year (Kavana et al., 2005). Using plant tolerance and organic amendment at saline soil resulted in higher forage production and carrying capacity compare to natural pasture and potential pasture.

Carrying capacity based on DM production of $P$. maximum and $S$. grandiflora with application 20 ton/ha, 10 ton/ha and 0 ton/ha manure at moderately saline soil were $10.8 \mathrm{AU} /$ ha/year, 7.2 $\mathrm{AU} / \mathrm{ha} /$ year and $2.3 \mathrm{AU} / \mathrm{ha} /$ year, respectively. Based on the equivalent calculation, total DM production available at treatment 20 ton/ha, 10 ton/ha and 0 ton/ha manure was able to support sheep as many as 77.0 head/ha/year, 51.1 head/ha/year and 16.4 head/ha/year, respectively. Whereas, the DM production available was able to support goat as many as $67.4 \mathrm{head} / \mathrm{ha} /$ year, 44.7 head/ha/year and $14.3 \mathrm{head} / \mathrm{ha} /$ year, respectively.

Jayanegara et al. (2017) recommended dry matter, crude protein and total digestible energy (TDN) intake for local sheep in Indonesia for both maintenance and gain. Sheep with body weight (BW) $20 \mathrm{~kg}$ and average daily gain (ADG) 100 $\mathrm{g} /$ day required $\mathrm{DM}, \mathrm{CP}$ and TDN intake in the 
amount of $765 \mathrm{~g} \mathrm{DM} /$ day, $109 \mathrm{~g} \mathrm{CP} /$ day and 530 g TDN/day, respectively. Based on those DM, CP and TDN intake recommendation, mixed cropping $P$. maximum and $S$. grandiflora with manure application 20 ton/ha could accomadated 104.3 sheeps based on DM, 93.6 sheeps based on CP and 91.6 sheeps based on TDN.

P. maximum and $S$. grandiflora are feed that has good quality and palatability for ruminant including small ruminant such as goat. $P$. maximum and $S$. grandiflora as feed can be used as a sole diet or supplemented with other forage. Hong Chin and Thi Hue (2012) reported DM intake of $P$. maximum and Tithonia diversifolia were $339.6 \mathrm{~g} /$ day and $226 \mathrm{~g} /$ day, respectively which resulted in live weight gain of goat was $60.7 \mathrm{~g} /$ day. Dry matter intake and live weight gain of goat fed $S$. grandiflora as sole diet were 800 g/day and $114 \mathrm{~g} /$ day, respectively (Nhan, 1998). Meanwhile, Lam and Ledin (2004) reported goat fed $S$. grandiflora as sole diet resulted DM intake and live weight gain were $339 \mathrm{~g}$ /day and 63.5 $\mathrm{g} /$ day, respectively. Live weight gain of goat fed P. maximum and S. grandiflora at 60\%: $40 \%$ proportion was $78.6 \mathrm{~g} / \mathrm{day}$, with DM intake of $P$. maximum and $S$. grandiflora were $558 \mathrm{~g} /$ day and 255 g/day, respectively (Kusmiyati et al., 2017).

\section{CONCLUSION}

Dry matter production, crude protein and carrying capacity of $P$. maximum and $S$. grandiflora were increased with application of 20 ton/ha manure at saline soil. Total production of dry matter, crude protein and total digestible nutrient of mixed cropping $P$. maximum and $S$. grandiflora at application 20 ton/ha manure were $29131 \mathrm{~kg} / \mathrm{ha} /$ year; $3722 \mathrm{~kg} / \mathrm{ha} /$ year and 17718 $\mathrm{kg} / \mathrm{ha} / \mathrm{year}$, respectively. Carrying capacity based on dry matter, crude protein and total digestible nutrients were $10.8 \mathrm{AU} / \mathrm{ha} /$ year; 13.6 AU/ha/year and $11.3 \mathrm{AU} / \mathrm{ha} /$ year, respectively.

\section{ACKNOWLEDGEMENT}

The authors would like to express gratitude to the Directorate General of Research and Community Service, Ministry of Research, Technology and Higher Education for its financial support through Institution Nasional Strategic grant 2016-2017 (contract number : 70079/UN7.5.1/PP/2017). An expression gratitude is also conveyed to the Research and Community Service Institute - Diponegoro University.

\section{REFERENCES}

Ahmad, M.S.A., M. Ashraf and Q. Ali. 2010. Soil salinity as a selection pressure is a key determinant for the evolution of salt tolerance in Blue Panic grass (Panicum antidotale Retz.). Flora 205(1):37-45.

Andrade CMS de; Farinatti LHE; Nascimento HLB do; Abreu AQ; Jank L; Assis GML de. 2013. Animal production from new Panicum maximum genotypes in the Amazon biome, Brazil. Trop. Grassl. 1(1):36-38.

Badan Pusat Statistik Kabupaten Rembang. 2017. Kabupaten Rembang dalam Angka. Badan Pusat Statistik Kabupaten Rembang.

Association of Official Analytical Chemists (AOAC). 2005. Official Methods of Analysis. AOAC Inc., Virginia.

Ates, S., H. Cicek, L.W. Bell, H.C. Norman, D.E. Mayberry, S. Kassam, D.B. Hannaway and M.Louhaichi. 2018. Sustainable development of smallholder crop-livestock farming in developing countries. IOP Conf. Ser. : Earth Environ. Sci. 142 : 012076

Bano, A and M.Fatima. 2009. Salt tolerance in Zea mays (L). following inoculation with Rhizobium and Pseudomonas. Biol. Fertility of Soils. 45(4):405-413.

Diaz, F.J., S.R. Grattan, J.A. Reyes, B. de la Roza-Delgado, S.E. benes, C. Jimenez, M. Dorta and M. Tejedor. 2018. Using saline soil and marginal quality water to produce alfalfa in arid climates. Agric. Water Manag. 199(1):11-21.

Fadiyimu, A.A., J.A. Alokan and A. N. Fajemisin. 2010. Digestibility, nitrogen balance and haematological profile of west African dwarf sheep fed dietary levels of Moringa oleifera as supplement to Panicum maximum. J. American Sci. 6(10):634-643.

Fang, S., H. Li, Q. Sun and L. Chen. 2010. Biomass production and carbon stocks in poplar-crop intercropping systems: a case study in northwestern Jiangsu, China. Agrofor. Syst. 79(2):213-222.

Ginting, S.P., K. Simanihuruk, Antonius and A. Tarigan. 2017. Growth and feed utilization of boer x kacang crossbred goats offered total mixed rations of different protein and energy levels. JITV. 22(4):188-195.

Hartadi, H., S. Reksohadiprodjo, S. Lebdosukojo, A.D. Tillman, L.C. Kearl and L.E. Harris. 
1980. Table of Feed Composition for Indonesia. IFI., Utah Agricultural Experiment Station, Utah State University, Logan, UT., USA., pp : 12.

Hong Chin, N. and K. Thi Hue. 2012. Supplementing Tithonia diversifolia with Guinea grass or tree foliages: effects on feed intake and live weight gain of growing goats. Livest. Res. Rural Dev. 24:Article \# 188.

Jayanegara, A., M. Ridla, D.A. Astuti, K.G. Wiryawan, E.B. Laconi and Nahrowi. 2017. Determination of energy and protein requirements of sheep in Indonesia using a meta-analytical approach. Med. Pet. 40(2):118-127.

Kavana, P.Y., J.B. Kizima, Y.N. Msanga, N.B. Kilongozi, B.S.J. Msangi, L.A. Kadeng'uka, S. Mgulu and P.K. Shimba. 2005. Potential of pasture and forage for ruminant production in Eastern zone of Tanzania. Livest. Res. Rural Dev. 17. Article \# 144.

Kearl, L.C. 1982. Nutrient Requirements of Ruminants in Developing Countries. International Feedstuffs Institute, Utah State University, Logan.

Kebede, G., G. Assefa, F.Feyissa and A. Mengistu. 2016. Forage legumes in croplivestock mixed farming systems - a review. International J. Livest. Res. 6(4):118.

Kimura, E., S. C. Fransen, H. P. Collins, B.J. Stanton, A. Himes, J. Smith, S.O. Guy, W.J. Johnston. 2018. Effect of intercropping hybrid poplar and switchgrass on biomass yield,forage quality, and land use efficiency for bioenergy production. Biomass Bioenergy . 111:31-38.

Kumar, U., H.N.N. Murthy, K.C. Singh, M.D. Gouri, Y.B. Rajeshwari, N.C. Siddeshawara, A. Mateen and R. Guruprasad. 2017. Biomass yield and chemical composition of Sesbania grandiflora and Moringa oleifera. Int. J. Sci. Environ. 6:3264-3269.

Kusmiyati, F. Sumarsono, Karno and E. Pangestu. 2012. Mineral concentration of forage grasses at different salinity levels of soil. Proceedings. The $2^{\text {nd }}$ International Seminar on Animal Industry, Bogor Agricultural Institute, Jakarta, Indonesia, July 5-July 6, 2012. P. 171-177

Kusmiyati, F., Sumarsono, Karno and E.
Pangestu. 2016. Influence of rice straw mulch on saline soil : forage production, feed quality and feed intake by sheep. J. Int. Soc. Southeast Asian Agric. Sci. 22(1):4251.

Kusmiyati, F., E.D. Purbajanti, Surahmanto and Sumarsono. 2017. Forage production in saline soil treated with organic fertilizer used as feed for growing goats. Livest. Res. Rural Dev. 29:Article \# 195.

Kusmiyati, F., E.D. Purbajanti and Surahmanto. 2018. The effects of manure at saline soil on growth, dry matter production an crude protein of $S$. grandiflora. IOP Conf. Ser. : Earth Environ. Sci. 119 :012023.

Lam, V. and I. Ledin. 2004. Effect of feeding different proportions of sweet potato vines (Ipomoea batatas L. (Lam)) and Sesbania grandiflora foliage in the diet on feed intake and growth of goats. Livest. Res. Rural Dev. 16, Article \#77

Lee, M.A., A.P. Davis, M.G.G. Chagunda and P. Manning. 2017. Forage quality declines with rising temperatures, with implications for livestock production and methane emissions. Biogeosci. 14:1403-1417.

Mbarki, S., A. Cerda, M.Zivcak, M.Brestic,M. Rabhi, M.Mezni, N. Jedidi,C. Abdelly and J.A. Pascual . 2018. Alfalfa crop amended with MSW compost can compensate the effect of salty water irrigation depending on the soil texture. Process Safety and Environ. Protect. 115:8-16.

Nhan, N. T. H .1998. Utilization of some forages as a protein source for growing goats by smallholder farmers. Livest. Res. Rural Dev. 10:Article \#23.

Ojo, V.O.A., P.A. Dele, T.A. Amole, U.Y. Anele, S.A. Adeoye, O.A. Hassan, J.A. Olonite and O.J. Idowu. 2013. Effect of intercropping Panicum maximum var. Ntchisi and Lablab purpureus on the growth, herbage yield and chemical composition of Panicum maximum var Ntchisi at different harvesting times. Pak. J. Biol. Sci. 16 (22):1605-1608.

Olonite, J.A., S.A. Tarawali and M.E. Ake'ova. 2009. Dry matter yields and botanical composition of three grasses and two legume mixtures grazed by cattle in a derived savanna area of Nigeria. J. Agric. Sci. Env. 9(1):28-38.

Qureshi, A.S. and A. Al-Falahi. 2015. Extent, characterization and causes of soil salinity in central and southern Iraq and possible 
recklamation strategies. Int. J. Engineering Res. Applications. 5(1):1-11.

Rinduwati., S. Hasan, J.A. Syamsu and D. Useng. 2016. Carrying capacity and botanical diversity of pastoral range in Gowa Regency. Int. J. Sci. Basic and Appl. Res. 29(3):105-111.

Rui-dong, H. 2018. Research progress on plant tolerance to soil salinity and alkalinity in sorghum. J. Integrative Agric. 17(4):739746.

Sarvade, S., Y.S.Parmar and Nauni. 2014. Sesbania grandiflora (L.) Poiret : A potential agroforestry tree species. Popular Kheti. 2(3):204-207.

Sastre-Conde, I., Carmen Lobo, M., Icela BeltranHernandez, R. And H.M. Poggi-Varaldo. 2015. Remediation of saline soils by a twostep process: Washing and amendment with sludge. Geoderma. 247:140-150

Se'u, V.E., P.D.M.H. Karti and L. Abdullah. 2015. Botanical composition, grass production, and carrying capacity of pasture in Timor Tengah Selatan District. Med. Pet. 38(3):176-182.

Shrivastava ,P and R. Kumar.2015. Soil salinity : a serius environmental issue and plant growth promoting bacteria as one of tools for its alleviation. Saudi J. Biol. Sci. 22(2):123-131.

Tahuk, P.K., S.P.S. Budhi, Panjono, N. Ngadiyono, R. Utomo, C.T. Noviandi and E. Baliarti. 2017. Growth performance of male Bali cattle fattening fed ration with different protein levels in smallholder farms, West Timor, Indonesia. Asian J.
Anim. Sci. 11(2):65-73.

Tahuk, P.K., S.P.S. Budhi, Panjono and. E. Baliarti. 2018. Carcass and meat characteristics of male Bali cattle in Indonesian smallholder farms fed ration with different protein levels. Trop. Anim. Sci. J. 41(3):215-223.

Vargas, R., E.S. Pankova, S.A. Balyuk, P.V.Krasilnikov and G.M. Khasankhanova. 2018. Handbook for Saline Soil Management. FAO of the United Nations.

Wu, H. 2018. Plant salt tolerance and $\mathrm{Na}^{+}$sensing and transport. The Crop J. 6(3): 215-225.

Wu, Y., Y. Li, C. Zheng, Y. Zhang and Z. Sun. 2013. Organic amendment application influence soil organism abundance in saline alkali soil. European J. Soil Biology. 54:3240.

Wu, H., L. Shabala, X. Liu, E. Azzarello, M. Zhou, C. Pandolfi, Z.H. Chen, J. Bose, S. Mancuso and S. Shabala. 2015. Linking salinity stress tolerance with tissue-specific $\mathrm{Na}+$ sequestration in wheat roots. Front. Plant Sci. 6:1-13.

Wu, Y., L. Yufei, Z.Yi., B.I. Yanmeng and S. Zhenjun. 2018. Response of saline soil properties and cotton growth to different organic amendments. Pedosphere. 28(3):521- 529

Yoottasanong, C., S. Pholsen and D.E.B. Higgs. 2015. Dry matter yields and forage quality of grass alone and grass plus legume mixture in relation to cattle manure rates and production methods. Pakistan J. Biol. Sci. 18(7):324-332 